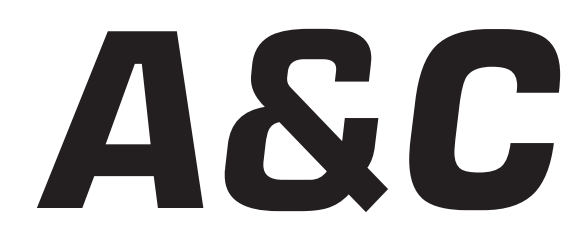

Revista de Direito Administrativo \& Constitucional

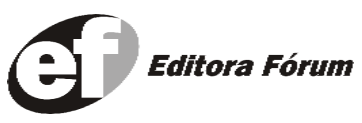

A\&C R. de Dir. Administrativo e Constitucional, Belo Horizonte, ano 5, n. 20, p. 1-255, abr.jun. 2005 


\section{A\&C REVISTA DE DIREITO ADMINISTRATIVO E CONSTITUCIONAL}

\section{IPDA}

Instituto Paranaense

de Direito Administrativo

Direção Geral

Romeu Felipe Bacellar Filho

Direção Editorial

Paulo Roberto Ferreira Motta

Direção Executiva

Emerson Gabardo

Conselho de Redação

Edgar Chiuratto Guimarães

Adriana da Costa Ricardo Schier

Célio Heitor Guimarães

Conselho Editorial

Adilson Abreu Dallari

Alice Gonzáles Borges

Carlos Ari Sundfeld

Carlos Ayres Britto

Carlos Delpiazzo

Cármen Lúcia Antunes Rocha

Celso Antônio Bandeira de Mello

Clèmerson Merlin Clève

Clóvis Beznos

Enrique Silva Cimma

Eros Roberto Grau

Fabrício Motta

Guilhermo Andrés Muñoz (in memoriam)

Jaime Rodríguez-Arana Muñoz

Jorge Luís Salomoni
José Carlos Abraão
José Eduardo Martins Cardoso

José Luís Said

José Mario Serrate Paz

Juan Pablo Cajarville Peruffo

Juarez Freitas

Julio Rodolfo Comadira

Luís Enrique Chase Plate

Lúcia Valle Figueiredo

Manoel de Oliveira Franco Sobrinho

(in memoriam)

Marçal Justen Filho

Marcelo Figueiredo

Márcio Cammarosano

Maria Cristina Cesar de Oliveira
Nelson Figueiredo

Odilon Borges Junior

Pascual Caiella

Paulo Eduardo Garrido Modesto

Paulo Henrique Blasi

Paulo Neves de Carvalho (in memoriam)

Paulo Ricardo Schier

Pedro Paulo de Almeida Dutra

Regina Maria Macedo Nery Ferrari

Rogério Gesta Leal

Rolando Pantoja Bauzá

Sérgio Ferraz

Valmir Pontes Filho

Yara Stropa

Weida Zancaner

\footnotetext{
A246 A\&C Revista de Direito Administrativo e Constitucional. ano 3, n. 11, jan./mar. 2003. Belo Horizonte: Fórum, 2003.

Trimestral

ano 1, n.1, 1999 até ano 2, n.10, 2002 publicada pela Editora Juruá em Curitiba

ISSN: 1516-3210

1. Direito Administrativo. 2. Direito Constitucional. I. Fórum.
}

CDD: 342 CDU: 33.342

(c) Editora Fórum Ltda. 2005

Todos os direitos reservados. É proibida a reprodução total ou parcial, de qualquer forma ou por qualquer meio eletrônico ou mecânico, inclusive através de processos xerográficos, de fotocópias ou de gravação, sem permissão por escrito do possuidor dos direitos de cópias (Lei $n^{\circ}$ 9.610, de 19.02.1998).

Editora Fórum Ltda

Av. Afonso Pena, 2770 - 15\%16ªndar - Funcionários

CEP 30130-007 - Belo Horizonte/MG - Brasil

Tel.: 08007043737

Internet: www.editoraforum.com.br

e-mail: editoraforum@editoraforum.com.br
Editor responsável: Luís Cláudio Rodrigues Ferreira Projeto gráfico e diagramação: Luis Alberto Pimenta Revisora: Olga M. A. Sousa

Pesquisa jurídica: Fátima Ribeiro - OAB/MG 74868

Bibliotecária: Nilcéia Lage de Medeiros

CRB 1545/MG 6a região

Os conceitos e opiniões expressas nos trabalhos assinados são de responsabilidade exclusiva de seus autores.

Impressa no Brasil / Printed in Brazil

Distribuída em todo Território Nacional 


\title{
Representação Judicial das Agências Reguladoras e Autarquias Federais: Aspectos Controvertidos e Distorções
}

\author{
Douglas Vitoriano Locateli \\ Advogado da União. Presidente da Associação Nacional dos Advogados da União - ANAUNI. \\ Membro do Grupo de Trabalho incumbido da elaboração de proposta para a reforma da Lei
} Orgânica da AGU

\begin{abstract}
Sumário: 1 Introdução - 2 Regime jurídico da Procuradoria-Geral Federal - 3 Breve desenvolvimento histórico da representação judicial da União. Natureza da vinculação conferida à procuradoria-geral federal - 4 Natureza dos entes da Administração indireta. Vinculação x hierarquia - 5 Principais distorções decorrentes da estrutura da PGF - 6 Proposição
\end{abstract}

\section{Introdução}

Este estudo foi desenvolvido e apresentado ao Grupo de Trabalho incumbido de elaborar proposta de anteprojeto de nova lei orgânica da Advocacia-Geral da União, ${ }^{1}$ com o propósito de apontar diretrizes e sugerir alterações legislativas voltadas ao incremento arrecadatório na área judicial, no âmbito da Procuradoria-Geral Federal, sem implicar em aumento de despesas. Também se objetiva alcançar eficiência na defesa judicial das agências reguladoras e autarquias federais, hoje excessivamente centralizada e afastada de seus objetivos institucionais. Contudo, antes de enfrentar a problemática e iniciar a abordagem do tema é indispensável conhecer o regime jurídico da Procuradoria-Geral Federal - PGF, seus antecedentes, bem como a problemática que envolve essa entidade.

\section{Regime jurídico da Procuradoria-Geral Federal}

A Procuradoria-Geral Federal foi criada pelo artigo $9^{\circ}$, da Lei $n^{\circ}$ 10.480, de 2 de julho de 2002, com natureza jurídica incerta. ${ }^{2}$ Trata-se de órgão dotado de autonomia administrativa e financeira, vinculado à 1 Portaria AGU n 386, de 16 de julho de 2004.

2 A respeito da natureza jurídica da PGF, assim pronunciou-se o Dr. Luiz Alberto dos Santos, Sub-chefe da SAG, Casa Civil, Presidência da República, em palestra proferida no V Encontro Nacional dos Advogados da União, evento realizado em Natal (RN), no período de 21 a 24 de outubro de 2004. "No caso da Procuradoria Geral Federal é uma coisa nova, criada recentemente. Portanto, a partir de um ordenamento constitucional que não deixa muitas dúvidas sobre quais os formatos que devem ser adotados para essa ou para aquela finalidade. Como órgão vinculado à $A G U$, representa pessoas jurídicas de direito público, que têm personalidade jurídica própria, me parece que deveria ser uma instituição da mesma natureza. Que por delegação dessas instituições assumisse a sua representação. Mas não é isso que está escrito na legislação, simplesmente diz órgão jurídico vinculado, só que vinculação é um instituto que se estabelece quando se tem uma instituição com personalidade jurídica própria. Vinculação a que ministério? O próprio Decreto-lei $n^{\circ} 200$ estabelece princípios para a vinculação de entidades da administração indireta aos respectivos

A \& C R. de Dir. Administrativo e Constitucional, Belo Horizonte, ano 5, n. 20, p. 63-75, abr./jun. 2005 
Advocacia-Geral da União, incumbido da representação de autarquias federais, sob a supervisão da Advocacia-Geral da União (art. 10, parágrafo único, da Lei $\left.\mathrm{n}^{\circ} 10.480 / 02\right)$. Mais adiante será analisada a natureza dessa vinculação, para concluir se ela se encontra estabelecida no artigo 131, do texto constitucional, ou se foi instituída somente pela Lei $\mathrm{n}^{\circ} 10.480 / 02$.

$\mathrm{O}$ artigo 10 , da Lei $\mathrm{n}^{\circ}$ 10.480/2002, estabelece competir à PGF a representação judicial e extrajudicial das autarquias e fundações públicas federais, as respectivas atividades de consultoria e assessoramento jurídicos, bem como a apuração da liquidez e certeza dos créditos, de qualquer natureza, inerentes às suas atividades, inscrevendo-os na dívida ativa para fins de cobrança amigável ou judicial. Esse dispositivo basicamente repetiu a mesma linha estabelecida pelo artigo 17, da Lei Complementar $\mathrm{n}^{\circ}$ 73/93, que conferiu aos departamentos de autarquias a natureza de órgãos vinculados à AGU. Recentemente foram feitas algumas alterações no sistema de arrecadação do INSS, introduzidas pela Medida Provisória $\mathrm{n}^{\circ}$ 222/2004, posteriormente convertida na Lei $n^{\circ} 11.098$, de 13 de janeiro de 2005, no sentido de autorizar a criação, na estrutura básica do Ministério da Previdência, da Secretaria da Receita Previdenciária (art. $8^{\circ}$, inciso I, da Lei $\mathrm{n}^{0} 11.098$, de 13 de janeiro de 2005), com competência para arrecadar, fiscalizar, lançar e normatizar o recolhimento, em nome do Instituto Nacional do Seguro Social, das contribuições sociais previstas nas alíneas "a", "b" e "c", do parágrafo único, do artigo 11, da Lei de custeio da Previdência Social (Lei $n^{\circ}$ 8.212/91), "e das contribuições instituídas a título de substituição, bem assim as demais competências correlatas e conseqüentes decorrentes do exercício daquelas, inclusive as relativas ao contencioso fiscal, conforme disposto em regulamento". (artigo $1^{\circ}$, da Lei $\left.\mathrm{n}^{\mathrm{o}} 11.098 / 05\right)$.

A Lei $n^{\circ} 11.098 / 05$ também transferiu da Procuradoria Federal Especializada - PFE-INSS para os demais órgãos da PGF — muitos ainda ministérios, ou órgãos supervisores. Mas no caso, a interpretação que eu me permito extrair da estrutura legal da Procuradoria Geral Federal é que ela é um órgão autônomo. O que é um órgão autônomo? Na vigência do Decreto-lei $n^{\circ} 200$, ela seria um órgão da administração direta com autonomia. Mas que tipo de autonomia? Aí variava do alfa ao ômega. Dependia do órgão. Então, nós tivemos isso até meados dos anos 90, mas com o governo Collor acabou, não existiram mais desde então, muitos dos órgãos autônomos existentes foram extintos, deixaram de ter autonomia, passaram a ser puramente órgãos da estrutura ministerial, não mais caracterizados como tais. No caso da Procuradoria Geral Federal, me parece que houve uma ressurreição dessa idéia: de um órgão autônomo no âmbito da AGU. Mas me parece realmente complicada a conceituação deste órgão, ainda mais a partir desse tipo de precedente, desse tipo de instrumento, até por conta da representação da administração indireta que é a sua tarefa. Em sendo órgão que representa a administração indireta, pertence à administração indireta. Então eu creio que temas dessa natureza, de fato requerem, exigem um pouco mais de reflexão, para que nós possamos estabelecer aí um patamar comum de entendimento, a respeito das possibilidades de solução." 
em fase de instalação - a representação judicial e extrajudicial relativas à execução da dívida ativa do INSS, referentes às contribuições sociais de que trata o artigo $1^{\circ}$, bem como o contencioso fiscal na Justiça do Trabalho.

Retirou-se, portanto, parte da competência daquela Procuradoria Federal Especializada, que permaneceu com a atribuição de representar judicialmente a autarquia (INSS) no contencioso de benefícios e nos juizados especiais. A Procuradoria Federal Especializada junto ao INSS também permaneceu responsável pela consultoria e assessoramento jurídico do Instituto Nacional do Seguro Social.

Não obstante a fiscalização tenha sido transferida para a União (Ministério da Previdência), os créditos apurados permanecem inscritos no INSS. Delineado o regime jurídico da PGF, pode-se iniciar a análise do texto constitucional, objetivando descortinar a natureza da vinculação entre a Procuradoria-Geral Federal e a Advocacia-Geral da União.

\section{Breve desenvolvimento histórico da representação judicial da União. Natureza da vinculação conferida à procuradoria-geral federal}

Existe entendimento, difundido por entidade de classe, que o "caput" do artigo 131, da Constituição, disciplinou como órgãos vinculados à Advocacia-Geral da União as procuradorias e departamentos jurídicos das autarquias e fundações públicas federais. Considera-se que as autarquias e as agências reguladoras se confundem com a União, o que possibilitou medida implementada durante o governo Fernando Henrique Cardoso, no sentido de repassar, em caráter provisório e excepcional, a representação de quase uma centena de entidades integrantes da administração indireta para a AGU, ${ }^{3}$ ao argumento de se conferir tratamento uniforme em matérias comuns às duas esferas. Para uma melhor compreensão dessa problemática é indispensável dar início a uma breve incursão histórica a respeito da representação judicial da União para, após, adentrar no regime constitucional da AGU. Ao final espera-se revelar os limites da organização e do funcionamento dessa Instituição.

Neste momento é necessário relembrar como se dava a representação judicial da União na vigência das Constituições que precederam a Carta de 1988. Criada a Justiça Federal pelo Decreto $n^{\circ} 848$, de 11 de outubro de 1890, foi somente com a Constituição de 1934 que se institucionalizou a Advocacia Pública da União, embora com a denominação de Minis3 Artigos 11-A e 11-B, da Lei n 9.028, de 12 de abril de 1995, acrescidos pela Medida Provisória 198415 e 16 e que atualmente possui o número 2.180-35, de 28 de abril de 2001. 
tério Público, como um dos órgãos de cooperação das atividades governamentais (artigos 95-98). A competência penal e sobre interesses privados indisponíveis passou para as justiças estaduais, de modo que o Ministério Público Federal tornou-se, na Constituição de 1934, fundamentalmente, o órgão de defesa dos interesses da União em Juízo.

Na vigência da Constituição de 1937 o Ministério Público estadual passou a auxiliar o Procurador-Geral da República na representação judicial da União. Remetida ao legislador ordinário a atribuição de disciplinar a competência e os recursos da dívida ativa da União, também se conferiu ao Ministério Público nos Estados a representação da Fazenda Nacional em Juízo.

Com o advento da Constituição de 1946, o Ministério Público Federal reassumiu, dentre outras funções, a representação judicial da União, aí incluída a cobrança da dívida ativa, cuja inscrição era feita pela Procuradoria-Geral da Fazenda Nacional, órgão do Ministério da Fazenda que também exercia a atividade de consultoria e o assessoramento jurídico daquela pasta. A atividade consultiva do Presidente da República era exercida pela Consultoria-Geral da República. Também se estabeleceu que, mediante lei, a competência para representar a União em Juízo poderia ser conferida, nas comarcas do interior, ao Ministério Público estadual.

Esse quadro permaneceu durante a vigência das Constituições de 1967 e 1969, sendo alterado somente depois de concluída a Assembléia Nacional Constituinte, o que se deu com a promulgação da Carta de 1988. Portanto, sob o ponto de vista histórico, a representação judicial da União jamais esteve relacionada à representação judicial ou extrajudicial da administração descentralizada. ${ }^{4}$

Durante a Assembléia Nacional Constituinte foram diversas as interferências e propostas de emendas formuladas por grupos de pressão que representavam, e ainda representam, os interesses profissionais de algumas categorias. Naquela época esses grupos pretenderam, sem êxito, ver aprovada proposição no sentido de criar uma carreira única ${ }^{5}$ em novo órgão, ainda em fase de elaboração na assembléia constituinte, que assumiria a representação judicial e extrajudicial da União e as atribuições da antiga Consultoria-Geral da República. Essa nova instituição, a Advocacia-

\footnotetext{
${ }^{4}$ LOCATELI, Douglas Vitoriano. Aspectos Históricos e Perspectivas da Advocacia Pública na Constituição de 1988. Debates em Direito Público - Revista de Direito dos Advogados da União, Campinas ano II, n. 2, out. 2003
}

A \& C R. de Dir. Administrativo e Constitucional, Belo Horizonte, ano 5, n. 20, p. 63-75, abr.jun. 2005 
Geral da União, encontra-se disciplinada pelo artigo 131, do texto constitucional e pela Lei Complementar ${ }^{\text {o }} 73 / 93 .^{6}$

A pretensão de se criar essa carreira única no âmbito da AdvocaciaGeral da União, e de implementar o aproveitamento de servidores, não foi acolhida. O constituinte optou por um órgão ágil e enxuto, fazendo expressa referência à necessidade de aprovação em concurso público de provas e títulos como requisito de ingresso na classe inicial das carreiras $^{7}$ e, conseqüentemente, na própria instituição. Disso conclui-se que a possibilidade de aproveitamento de profissionais pertencentes a outras carreiras, como forma de provimento derivado e de ingresso na AdvocaciaGeral da União, não foi acolhida pelo constituinte. Saliente-se que o Supremo Tribunal Federal, em decisão proferida na ADI $n^{\circ}$ 2.713/02, estabeleceu critério objetivo a respeito do tema na oportunidade em que analisou a transformação de cargos de Assistente Jurídico da AGU em cargos de Advogado da União, ${ }^{8}$ confirmando a necessidade de aprovação em concurso público para ingresso na Advocacia-Geral da União.

Estabelece o artigo 131, da Constituição da República, que $a$ Advocacia-Geral da União é a instituição que, diretamente ou através de órgão vinculado, representa a União, judicial e extrajudicialmente, cabendo-lhe, nos termos da lei complementar que dispuser sobre sua organização e

\footnotetext{
5 A carreira única, que se pretendeu criar, denominada Procurador da União, teria seus cargos posteriormente ocupados por assistentes jurídicos da União e por procuradores autárquicos federais. Estes últimos, por força da MP 2.229/01, foram transformados em Procuradores Federais e integram o quadro próprio da Procuradoria-Geral Federal (vide os artigos 39 e 40 da MP 2.229 e o artigo 12, da Lei no 10.480, de 02 de julho de 2002). Alguns antigos assistentes jurídicos da União obtiveram êxito e foram transpostos para a carreira de Assistente Jurídico da AGU (vide artigo 19, da Lei n 9.028/95). Transformados os cargos de Assistente Jurídico da AGU em cargos de Advogado da União e extinta a carreira de Assistente Jurídico da AGU, por força do artigo 11, da MP 43/2002, posteriormente convertida na Lei $n^{\circ} 10.549$, de 13 de novembro de 2002, alguns daqueles ex-Assistentes Jurídicos da União, atualmente, ocupam cargos de Advogados da União, situação essa que destoa totalmente dos critérios estabelecidos pelo STF para a transformação de cargos e, conseqüentemente, afronta o artigo 131, parágrafo $2^{\circ}$, do texto constitucional. A idéia de instituir carreira única ainda é avivada constantemente junto ao Advogado-Geral da União, conforme se pode perceber pela leitura de texto elaborado pela Procuradora Federal que ocupa o cargo de Secretária-Geral de Consultoria da Advocacia-Geral da União, Dra. Maria Jovita Wolney Valente, assessora direta do atual Advogado-Geral da União, Ministro Álvaro Augusto Ribeiro Costa (vide AGU - Legislação. Secretaria-Geral de Consultoria. Caderno 1, 2004. p. 20, item 48).

6 O artigo 20 da Lei Complementar n० 73/93, alterado pelo artigo 11, da Lei $n^{\circ} 10.549$, de 2 de julho de 2002, estabelece serem carreias da AGU as de Advogado da União e Procurador da Fazenda Nacional.

7 A Constituição estabelece apenas uma exceção, expressa no parágrafo $3^{\circ}$, artigo 29 , do ADCT, que possibilitou aos membros do Ministério Público admitidos antes da Promulgação da Constituição de 1988 a opção pelo regime anterior no tocante às garantias e vantagens, configurando regra de exceção aos artigos $128, \S 5^{\circ}$ e $131, \S 2$, do texto constitucional. Dessa forma, aos membros do Ministério Público abrangidos por essa norma possibilita-se exercer outra função ou cargo público de igual ou superior relevância na administração pública (Ministros ou Secretários de Estado, por exemplo), conforme era permitido pela Constituição anterior e pela anterior Lei Orgânica do Ministério Público (LC n 40/81).

$8 \mathrm{ADI} n^{\circ}$ 2.713/02, ajuizada pela Associação Nacional dos Advogados da União - ANAUNI, que teve como relatora a Ministra Ellen Gracie. A respeito do tema "transformação de cargos na Advocacia-Geral da União", o plenário do Pretório Excelso entendeu possível a medida, inclusive no âmbito do Ministério Público da União, quando estiverem presentes os seguintes requisitos: identidade de atribuições, idêntica tabela de vencimentos e, compatibilidade dos requisitos de ingresso exigidos em concurso público para provimento de ambos os cargos.
} 
funcionamento, as atividades de consultoria e assessoramento do Poder Executivo.

Também estabelece o parágrafo $3^{\circ}$, do mesmo dispositivo, que na execução da dívida ativa de natureza tributária a representação da União cabe à Procuradoria-Geral da Fazenda Nacional, observado o disposto em lei. Vale ressaltar ser, a PGFN, o órgão do Ministério da Fazenda que representa a União nas causas de natureza fiscal. Historicamente ela sempre inscreveu os débitos de natureza tributária da União na dívida ativa, como também sempre desempenhou a atividade de consultoria e assessoramento jurídico no âmbito do Ministério da Fazenda. Promulgada a Constituição de 1988, por força dos artigos 131, parágrafo $3^{\circ}$, da Constituição, e 29, parágrafo $5^{\circ}$, do ADCT, passou imediatamente a representar a União nas causas de natureza fiscal.

Considerando esses antecedentes históricos e a vontade do constituinte originário, conclui-se que a expressão "União", contida no "caput" do artigo 131, refere-se apenas à pessoa jurídica central de direito público interno. O órgão vinculado, ali referido, é a Procuradoria-Geral da Fazenda Nacional, ${ }^{9}$ pois é por intermédio dessa Procuradoria que a AGU representa judicialmente a União em matéria fiscal. ${ }^{10}$

Argumenta-se que a expressão "União", contida no referido dispositivo, refere-se à pessoa política (administração pública federal), abarcando, assim, agências reguladoras, autarquias e fundações. Para solucionar essa divergência interpretativa recorre-se à análise sistemática do texto constitucional. Nesse sentido, verifica-se que quando a Constituição se refere às entidades da administração pública, direta e indireta, bem como às demais entidades componentes da federação, o faz expressamente, distinguindo a União de suas autarquias e fundações, conforme se pode constatar pela leitura dos artigos: 40; 52, inciso VII; $150, \S 2^{\circ} ; 157$, inciso I; 158 , inciso 9 A expressão "vinculado", utilizada no texto do "caput", do artigo 131, referida à PGFN, expressa uma impropriedade técnica do legislador, pois no âmbito da União os órgãos que a integram submetem-se ao controle hierárquico; não ao controle finalístico das entidades componentes da Administração Indireta. Embora a PGFN esteja inserida na estrutura do Ministério da Fazenda, encontrando-se subordinada administrativamente àquele órgão, também está, sob o ponto de vista hierárquico, tecnicamente subordinada à Advocacia-Geral da União. Conclui-se que PGFN está submetida a uma dupla subordinação no sistema da Advocacia-Geral da União.

${ }^{10}$ Diário da Assembléia Nacional Constituinte, p 9332, 13.04.1988. O Deputado Gastone Rigui, na Assembléia Nacional Constituinte, manifestou-se da seguinte forma em relação à Procuradoria-Geral da Fazenda Nacional: "Hoje, Sr. Presidente, Srs. Constituintes, a Procuradoria da Fazenda Nacional é um órgão já antigo, de cento e oitenta anos, foi fundada em, 1808, antes da independência do País; esse órgão inscreve os débitos e os créditos fiscais da União na dívida ativa, mas não tem competência para cobra-los em juízo. Esta cobrança dispersa-se na Procuradoria-Geral da República e nas procuradorias estaduais. Como resultado prático dessa dispersão, hoje a União tem a cobrar créditos fiscais no valor de quatrocentos e sessenta bilhões de cruzados, $2 \%$ do PIB, mais do que o governo tenta recuperar com o congelamento da URP para o funcionalismo público. É preciso dar agilidade e efetividade a esse organismo, porque indispensável às conveniências do interesse público e às conveniências da União."

A \& C R. de Dir. Administrativo e Constitucional, Belo Horizonte, ano 5, n. 20, p. 63-75, abr.jun. 2005 
I; 160, parágrafo único, inciso I; 163, inciso II; 202, $\S \S 3^{\circ}, 4^{\circ}$, da Constituição, bem como dos artigos 29 e 72, inciso I, do ADCT.

Importante ressaltar, ainda, que o artigo 131, do texto constitucional, fala em representação judicial da União. Não se pode olvidar que representação é instituto processual e implica em fazer alguém presente. Conforme esclarece Aurélio Buarque de Holanda, representar é ser mandatário de alguém, pois apenas pessoas podem estar em Juízo. Assim sendo, a expressão União só pode ser compreendida como pessoa jurídica de direito publico e não como sinônimo de administração pública federal.

Por fim, argumenta-se no sentido de que a expressa referência às Procuradorias e Departamentos Jurídicos de autarquias federais, com representação própria, e aos membros das Procuradorias das Universidades fundacionais públicas, contida na regra de transição do artigo 29, do ADCT, conduziria o intérprete à conclusão de que a Advocacia-Geral da União, ao assumir as funções de representação da União, passaria também a representar a administração descentralizada.

Ocorre que o artigo 29, do ADCT, não transferiu para a AdvocaciaGeral da União a atribuição de representar judicialmente autarquias e fundações públicas; apenas possibilitou que eventual vinculação estabelecida entre a União (AGU) e uma ou algumas entidades da Administração Indireta fosse regulamentada em sede de Lei Complementar. Na verdade, a Lei Complementar deve estabelecer os limites dessa vinculação, tais como: submissão às correições da AGU, bem como às súmulas e orientações normativas do Advogado-Geral da União, ressaltando que essa vinculação conduz à idéia de que a Procuradoria-Geral Federal - PGF possui personalidade jurídica própria. Contudo, jamais se poderia pensar que esse dispositivo autoriza a assunção, pela AGU, das atribuições próprias da administração descentralizada. ${ }^{11}$

Conclui-se que a vinculação existente entre a Procuradoria-Geral Federal e a Advocacia-Geral da União não é de natureza constitucional, mas foi implementada no ato de sua criação, pelo artigo $9^{\circ}$, da Lei $n^{\circ}$ 10.480/2002. Essa "vinculação", bem como aquela estabelecida, historicamente, pelo

\footnotetext{
${ }^{11}$ Conforme as lições do Dr. Marcos Luiz da Silva, Advogado da União, Professor Efetivo da Universidade Estadual do Piauí e Pós-Graduado em Direito Processual pela ESAPI/UFPI. Passo a transcrever trecho de mensagem eletrônica por ele encaminhada, tecendo algumas considerações a respeito do tema PGF: "A lei complementar do MPF e da Defensoria Pública traz em seu texto regulamentação dos órgãos federais e estaduais, sem confusão ou fusão entre esses. A lei orgânica da Magistratura Nacional também o faz. Nada impede que uma lei orgânica da Advocacia Pública Federal traga em seu bojo normas sobre a AGU, os órgãos vinculados (aí incluída a PGF), e a PGFN, sem que haja qualquer distorção. Outrossim, a PGF é uma instituição que se encontra em plena expansão, de modo que se torna, sob o ponto de vista prático, inviável a sua inclusão na AGU, ou a transferência de suas atribuições para AGU."
} 
artigo 17, da Lei Complementar $\mathrm{n}^{\circ}$ 73, de 10.02.1993, deve receber interpretação conforme o texto constitucional. Nesse particular a Lei $\mathrm{n}^{\mathrm{o}}$ 10.480/02 apresenta inconstitucionalidade formal e material, uma vez que trata de matéria reservada à lei complementar, além de restringir a autonomia das agências reguladoras e das demais entidades da administração pública descentralizada.

\section{Natureza dos entes da Administração indireta.} Vinculação x hierarquia

No direito brasileiro, autarquias são definidas como pessoas de direito público dotadas de autonomia, criadas por lei, com patrimônio e receita próprios, destinadas à execução de atividades públicas que requeiram, para seu melhor funcionamento, gestão administrativa e financeira descentralizada. O Decreto-lei no 200 as define como "pessoas jurídicas de Direito Público de capacidade exclusivamente administrativa" ${ }^{12}$.

Na condição de pessoas jurídicas tais entidades gozam de liberdade administrativa e financeira; ou seja, as gestões administrativa e financeira são de sua alçada — logo, descentralizadas. ${ }^{13}$ Não se pode perder de vista, contudo, o caráter instrumental dessa autonomia, na medida em que se apresenta como elemento indispensável ao alcance dos objetivos que justificam a criação dessas entidades. Esse caráter instrumental há de ser observado, sempre, quando tratamos de descentralização administrativa. Esse elemento, por sua vez, nos remete a um outro aspecto; o de que a Entidade central também poderá supervisionar, controlar, a eficácia dessa liberdade administrativa e financeira. Se a autonomia (administrativa e financeira) pode ser compreendia como um direito do Ente descentralizado, por outro lado esse Ente, autônomo, também possui o dever de se desincumbir da missão institucional que motivou sua criação. Tal situação os coloca sob a fiscalização do Poder Público que os instituiu. "Esse duplo aspecto é essencial para que se possa compreender a extensão do controle sobre os entes descentralizados; ele só vai até onde não ofenda a capacidade de auto-administração delimitada por lei; por sua vez, essa capacidade de auto-administração vai até onde não esbarre com os atos de controle previstos em lei." 14

O controle/tutela (espécie que, juntamente com o controle hierárquico e a autotutela, compõem modalidades do gênero "controle Administrativo") 12 MELLO, Celso Antônio Bandeira de. Curso de Direito Administrativo. 13. ed. São Paulo: Malheiros, p. 123. ${ }^{13}$ Op. cit., p. 124.

A \& C R. de Dir. Administrativo e Constitucional, Belo Horizonte, ano 5, n. 20, p. 63-75, abr.jun. 2005 
somente pode ser determinado por lei. Como elemento restritivo da autonomia ele não se presume; constitui-se em uma soma de competências particulares atribuídas explicitamente por lei, que não podem ser acrescidas, nem por analogia. ${ }^{15}$ Esse controle, porém, não significa que os Entes descentralizados estejam hierarquicamente subordinados à Administração Direta. Existirá uma vinculação para fins de controle finalístico, apenas. "Essa vinculação normalmente se dá com relação ao Ministério ou Secretaria de Estado ou de Município cujas atividades se relacionam com a da pessoa jurídica da administração indireta" (Maria Sylvia Zanella Di Pietro).

Antes da criação da PGF as autarquias dispunham de órgãos jurídicos integrados em suas respectivas estruturas administrativas, que desempenhavam atividade meio, voltados ao alcance de objetivos institucionais específicos. A estruturação da PGF não pode significar a perda dessa identidade finalística, a ponto de comprometer o alcance desses objetivos legalmente estabelecidos e, conseqüentemente, das autonomias. Ou seja, a PGF pode ser aparelhada e estruturada, mas também deve ser preservada sua identidade instrumental, herdada ontologicamente dos antigos Departamentos Jurídicos das autárquicas, destinados ao alcance dos objetivos que, por lei, foram confiados à administração indireta. ${ }^{16}$

\section{Principais distorções decorrentes da estrutura da PGF}

A PGF representa diversas agências reguladoras e autarquias federais, cada qual com sua peculiaridade e importância, mas não se pode olvidar que uma delas se notabiliza nesse contexto, pois seu contencioso representa 95\% (noventa e cinco por cento) das demandas conduzidas pela Procuradoria-Geral Federal. Refiro-me ao Instituto Nacional do Seguro Social - INSS - o maior litigante do Poder Judiciário Brasileiro. Essa entidade é autora, ré ou parte interessada em milhões de processos que tramitam não apenas na Justiça Federal (comum e do trabalho), mas também nas demandas processadas em comarcas que não possuem Vara Federal instalada. Segundo levantamento realizado pela Procuradoria

\footnotetext{
${ }^{14}$ DI PIETRO, Maria Sylvia Zanella. Direito Administrativo. 14. ed. São Paulo: Atlas: 2002. p. 408 et seq.

15 MEDAUAR, Odete Referida por DI PIETRO, Maria Sylvia Zanella, op. cit., p. 408.

16 Nesse mesmo sentido foram as manifestações de diversos Advogados da União, em debates realizados no $V$ Encontro Nacional dos Advogados da União. Não se pode, a propósito de um interesse grupal que deseja integrar a administração direta, subtrair parcela de autonomia das entidades da administração indireta, que possuem personalidade e atribuições conferidas por lei e, em decorrência disso, também possuem capacidade processual própria destinada à defesa de seus interesses, que pode ser exercitada, inclusive, em face da Administração Direta. Retirar os advogados dessas entidades implica na subtração da autonomia.
}

A \& C R. de Dir. Administrativo e Constitucional, Belo Horizonte, ano 5, n. 20, p. 63-75, abr./jun. 2005 
Federal Especializada no INSS, o Instituto tem ações em todas as comarcas do País. De posse dessas informações torna-se fácil afirmar que a PGF possui preponderantemente natureza de Procuradoria Previdenciária, mas que também englobou a representação das demais autarquias, sem que se implementasse a necessária redistribuição de trabalho entre seus órgãos.

Se a criação da carreira de Procurador Federal teve por objetivo implementar racionalidade e eficiência na defesa da Administração Indireta, ${ }^{17}$ esses valores não foram aplicados à PFE-INSS e à PGF, em razão de distorções graves decorrentes da ausência de critério na distribuição desses profissionais, acarretada pela excessiva centralização administrativa, pois recente levantamento efetuado junto ao Poder Judiciário revela que nas unidades jurídicas da Procuradoria Federal Especializada junto ao INSS a média de processos, por Procurador, é superior a 4.000 (quatro mil). Em algumas unidades essa distorção é bem maior, alcançando a média de 10.000 (dez mil) processos por procurador. ${ }^{18}$ Nesse contexto, existem unidades jurídicas da PGF, que representam as demais autarquias, com médias bem inferiores, ${ }^{19}$ sem que se façam os necessários remanejamentos. Essa carência vem gerando graves prejuízos financeiros ao erário. E mais, existem Procuradores Federais com exercício provisório em órgãos consultivos e em Procuradorias da União, distorção provocada pela excessiva e indevida concentração de competências conferidas ao Advogado-Geral da União. ${ }^{20}$ Esse fato inviabiliza a autonomia administrativa que deve ser conferida à PGF para que alcance sua finalidade; representar eficientemente as entidades da Administração Indireta, ressalvado o Banco Central do Brasil, que possui quadro jurídico integrado em sua estrutura.

Essa excessiva centralização de atribuições provoca a manutenção dos problemas que justificaram a criação da PGF e a criação da carreira de Procurador Federal, pois as condições humanas nas unidades da PFE-INSS permanecem precárias, a ponto de faltar procuradores para a prática de todos os atos processuais. Nos Juizados Especiais Federais de capitais como Maceió e Teresina, por exemplo, diante do diminuto quadro de procuradores, as audiências são acompanhadas exclusivamente por

\footnotetext{
${ }_{17}$ AGU - Legislação. Secretaria-Geral de Consultoria. Caderno 1, p. 16, itens 27 e 28. 2004.

18 Dados obtidos de relatório elaborado pela Procuradoria Federal Especializada junto ao INSS.

${ }^{19}$ Belo Horizonte/MG: média de 6.982 no INSS por procurador (335.173 processos para 48 procuradores); IBAMA apresenta 146 processos para 9 procuradores - uma média de 16,22 processos por procurador; o INCRA possui 608 processos para 14 procuradores, o que perfaz uma média de 43,42 processos por procurador. Essa mesma distorção apresenta-se em todos os Estados.

${ }^{20} \mathrm{O}$ artigo 12, da Lei n⿳ 10.480/02, ao fixar a competência do Advogado-Geral da União relativamente à carreira de Procurador Federal e seus Membros, estabelece que o AGU poderá determinar exercício provisório de Procurador Federal em órgãos da Advocacia-Geral da União.
} 
servidores administrativos do INSS que, na condição de prepostos, dizem sobre a possibilidade e a forma de acordos judiciais. ${ }^{21}$

De outra parte, estima-se que a sonegação fiscal, perante a Justiça do Trabalho, é superior a $\mathrm{R} \$ 2,4$ bilhões de reais por ano. A principal causa é a atuação insuficiente da Procuradoria que participa em menos de $20 \%$ dos processos, exigindo o correto recolhimento da contribuição previdenciária.

Essa situação é agravada em razão do processo de interiorização da Justiça Federal (comum e do trabalho) que está em acentuado desenvolvimento. Em 2004 foram instaladas 123 Varas Federais sendo que mais 60 Varas serão instaladas em 2005. Na Justiça do Trabalho estima-se a instalação de mais 249 Varas, o que diminuirá ainda mais a participação do órgão em processos que tramitam perante a Justiça do Trabalho, pois as Procuradorias não especializadas da PGF não apresentam capilaridade necessária ao atendimento da demanda de processos, uma vez que se encontram instaladas apenas em algumas capitais. Diante desses dados verifica-se que a medida implementada pelo artigo $2^{\circ}$, da Lei $\mathrm{n}^{\circ} 11.098 / 2005$ aumentará para muito além de $\mathbf{R} \$ 2,4$ bilhões, por ano, a sonegação fiscal perante a Justiça do Trabalho, pois não está prevista para 2005 a instalação de Procuradorias Seccionais Federais ${ }^{22}$ e nem todas as capitais dos Estados possuem Procuradorias Federais não especializadas instaladas.

Outra distorção está diretamente relacionada com o caráter instrumental da autonomia, na medida em que esse elemento é indispensável ao alcance dos objetivos que reclamaram a descentralização administrativa. Autonomia, repito, significa liberdade de atuação dentro dos limites definidos em lei. Ocorre que em diversas situações as autarquias litigam contra a própria União, como na hipótese de instalação de hidroelétricas, onde o Ente federal pretende ver implementado programa de expansão energética e o IBMA pretende a preservação do meio ambiente. Em outra hipótese a Agência Nacional de Transportes Aquaviários - ANTAQ ingressa como assistente no pólo ativo em Ação Popular promovida contra

${ }^{21}$ Informação obtida junto à Procuradoria Federal Especializada junto ao INSS.

22 Conforme notícia veiculada na rede agu, em 14.12.2004, às 18h58: "O procurador-chefe da União no Acre, Israel Pinheiro Torres Junior, questionou se há um estudo para agilizar a transferência de advogados do contencioso para o consultivo. O advogado-geral da União, ministro Álvaro Augusto Ribeiro Costa, disse que propiciar a remoção sem que isso signifique remoção e fazer um entendimento com as consultorias jurídicas. "Tudo isso deve ser resolvido", disse ele. O PU-Acre questionou ainda se há algum projeto para implantar procuradorias seccionais federais ou devolver a representação judicial aos órgãos da administração indireta. A procuradora-geral Federal, Célia Maria Cavalcanti Ribeiro, disse que não há previsão de criação destas procuradorias seccionais para o próximo ano. Porém, prevê soluções como a de Petrolina, em que a Cefet tem a representação judicial. Segundo ela, a prioridade é instalar as Procuradorias Regionais Federais. "Mas é possível que nós possamos nos adiantar. A implantação da PGF é feita de forma gradativa", disse Célia Ribeiro." 
concessionária de serviço público federal, após se dar o ingresso da União no pólo passivo. ${ }^{23}$ De que forma os Procuradores Federais poderão, nesse contexto, defender o interesse público confiado às autarquias caso submetidos hierarquicamente às orientações do Advogado-Geral da União? Caso recente decidido pelo Supremo Tribunal Federal no dia 16.12.2004 tomou espaço na mídia. A Universidade de Brasília, por intermédio do Ministério Público Federal, impugnou parecer da Advocacia-Geral da União que considerou constitucionais as transferências de filhos de militares egressos de instituições particulares de ensino superior. ${ }^{24}$ Esse parecer neutralizou a autonomia da UNB, provocando um colapso no sistema de ensino daquela Universidade, em especial no curso de Direito, que não ofertaria vagas no exame vestibular de 2005. Esse fato não é isolado e evidencia que, na hipótese de manutenção do regime jurídico atual, submetendo a PGF à modalidade de controle hierárquico, as agências reguladoras e demais entidades autárquicas representadas por aquela entidade ver-se-ão impedidas de alcançar suas finalidades institucionais, comprometendo a continuidade da prestação de serviços públicos indispensáveis ao País.

\section{Proposição}

A Procuradoria-Geral Federal representa a administração descentralizada, composta por Entes que possuem personalidade jurídica própria e que se submetem tão-somente ao controle finalístico da União. Considerando o ordenamento constitucional vigente e o aspecto pragmático, não é possível a inserção da Procuradoria-Geral Federal na estrutura orgânica da Advocacia-Geral da União; tampouco é cabível a ingerência da AGU

\footnotetext{
${ }^{23}$ Ação Popular n.e 2003.61.04.001241-6, processada na $4^{a}$ Vara Federal - Seção Judiciária de Santos.

${ }^{24}$ Vide Informativo STF n. 374 - ADI n 3324/DF, Relator Min. Marco Aurélio. O STF julgou procedente, em parte, pedido de ação direta ajuizada pelo Procurador-Geral da República contra o art. $1^{\circ}$ da Lei no 9.536/ 97 que prevê a possibilidade de efetivação de transferência "ex officio" de estudantes - servidores públicos civis ou militares, ou de seus dependentes - entre instituições vinculadas a qualquer sistema de ensino superior, quando requerida em razão de remoção ou transferência de ofício desses servidores que acarrete mudança de seu domicílio. Não obstante considerar consentânea com o texto constitucional a previsão normativa asseguradora do acesso a instituição de ensino na localidade para onde é removido o servidor, entendeu-se que a possibilidade de transferência entre instituições não congêneres permitida pela norma impugnada, especialmente a da particular para a pública, haja vista a envergadura do ensino, a própria gratuidade e a escassez de vagas oferecidas pela última, acabou por conferir privilégio, sem justificativa, a determinado grupo social em detrimento do resto da sociedade, a violar os princípios da isonomia, da impessoalidade e da moralidade da Administração Pública, da igualdade de condições para o acesso e permanência na escola superior (CF, art. 206, I) e a garantia do acesso aos níveis mais elevados do ensino (CF, art. 208, V). Por conseguinte, assentou-se a inconstitucionalidade do art. $1^{\circ}$ da Lei $n^{\circ}$ 9.536/97, sem redução do texto, no que se Ihe empreste o alcance de permitir a mudança, nele disciplinada, de instituição particular para pública, encerrando a cláusula "entre instituições vinculadas a qualquer sistema de ensino" a observância da natureza privada ou pública daquela de origem, viabilizada a matrícula na congênere, isto é, dar-se-á a matrícula em instituição privada se assim o for a de origem e em pública se o servidor ou o dependente for egresso de instituição pública.
} 
na administração da PGF.

A alternativa viável é conferir, explicitamente, natureza jurídica autárquica à Procuradoria-Geral Federal, vinculando-a à Advocacia-Geral da União para efeito de controle finalístico, em sede de lei complementar. Com essa medida a Procuradoria-Geral Federal adquirirá autonomia administrativa para implementar a redistribuição dos Procuradores Federais, de modo a alcançar eficiência na defesa das agências reguladoras e demais autarquias federais. Saliente-se que tal medida não acarretará aumento de despesa, uma vez que a PGF dispõe de orçamento próprio.

Por fim, são inconstitucionais os artigos 11-A e 11-B, da Lei n ${ }^{\circ}$ 9.028, de 12 de abril de 1995, acrescidos pela Medida Provisória $n^{\circ}$ 2.180-35, de 28 de abril de 2001, quando conferem à Advocacia-Geral da União a representação judicial da administração pública descentralizada.

Informação bibliográfica deste texto, conforme a NBR 6023:2002 da Associação Brasileira de Normas Técnicas (ABNT):

LOCATELI, Douglas Vitoriano. Representação Judicial das Agências Reguladoras e Autarquias Federais: Aspectos Controvertidos e Distorções. AE $\mathcal{F}^{2} \mathrm{C}$ Revista de Direito Administrativo e Constitucional, Belo Horizonte, ano 5, n. 20, p. 63-75, abr./jun. 2005. 